\title{
In vitro antiviral activity against SARS-CoV-2 of plant extracts used in Colombian traditional medicine
}

\author{
Actividad antiviral in vitro contra el SARS-CoV-2 de extractos \\ de plantas usados en medicina tradicional colombiana
}

Lizdany Flórez-Álvarez ${ }^{1}{ }^{\circledR}$, Jahnnyer Martínez-Moreno ${ }^{2(0)}$, María I. Zapata-Cardona ${ }^{10}$, Elkin Galeano ${ }^{3}$, Fernando Alzate-Guarin ${ }^{4}{ }^{\mathbb{C}}$, Wildeman Zapata ${ }^{1,5^{*}}$

JOURNAL VITAE

School of Pharmaceutical and Food Sciences ISSN 0121-4004 | ISSNe 2145-2660 University of Antioquia Medellin, Colombia

Filliations

${ }^{1}$ Grupo Inmunovirología, Facultad de Medicina, Universidad de Antioquia UdeA, Medellín, Colombia.

2 Grupo Salud y Comunidad, Facultad de medicina, Universidad de Antioquia UdeA, Medellín, Colombia.

${ }^{3}$ Grupo de Investigación en Sustancias Bioactivas -GISB, Departamento de Farmacia, Facultad de Ciencias Farmacéuticas y Alimentarias, Universidad de Antioquia UdeA Medellín, Colombia.

${ }^{4}$ Grupo de Estudios Botánicos, Instituto de Biología, Universidad de Antioquia Medellín, Colombia.

${ }^{5}$ Grupo Infettare, Facultad de Medicina, Universidad Cooperativa de Colombia, Medellín, Colombia.

*Corresponding

Wildeman Zapata

wildeman.zapatab@campusucc.edu.co

Received: 23 October 2021

Accepted: 5 January 2022 Published: 05 February 2022

\begin{abstract}
Background: Coronavirus infectious disease 2019 (COVID-19) caused by the infection with the new coronavirus SARS-CoV-2 has affected the life and health of more than 222 million people. In the absence of any specific pharmacological treatment, the need to find new therapeutic alternatives is clear. Medicinal plants are widely used worldwide to treat different conditions, including COVID-19; however, in most cases, there are no specific studies to evaluate the efficacy of these treatments. Objective: This article evaluates the antiviral effect of six plant extracts used by indigenous and afro Colombian people against SARS-CoV-2 in vitro. Methods: The antiviral effect of six extracts prepared from plants used in Colombian traditional medicine was evaluated against SARS-CoV-2 through a pre-post treatment strategy on the Vero E6 cell line. Once cytotoxicity was established through an MTT assay, the antiviral effect of the extracts was calculated based on the reduction in the viral titer determined by plaque assay. Results: Gliricidia sepium inhibited SARS-CoV-2 in a $75.6 \%, 56.8 \%, 62.5 \%$ and $40.0 \%$ at $10 \mathrm{mg} / \mathrm{mL}, 8 \mathrm{mg} / \mathrm{mL}, 6 \mathrm{mg} / \mathrm{mL}$, and $2 \mathrm{mg} / \mathrm{mL}$, respectively, while Piper tuberculatum treatment reduced viral titer in $33.3 \%$ at $6 \mathrm{mg} / \mathrm{mL}$ after $48 \mathrm{~h}$. Conclusion: G. sepium and P. tuberculatum extracts exhibit antiviral activity against SARS-CoV-2 in vitro.
\end{abstract}

Keywords: SARS-CoV-2, Plant extract, Antiviral agents, Ethnobotany. 


\section{RESUMEN}

Introducción: La enfermedad infecciosa causada por el coronavirus 2019 (COVID-19) generada por la infección con el nuevo coronavirus SARS-CoV-2 ha afectado la vida y la salud de mas de 222 millones de personas. En ausencia de algún tratamiento farmacológico específico, la necesidad de encontrar nuevas alternativas terapéuticas es clara. Las plantas medicinales son utilizadas en todo el mundo para tratar diferentes condiciones, incluyendo el COVID-19; sin embargo, en la mayoría de los casos no existen estudios específicos que evalúen la eficacia de estos tratamientos. Objetivo: En este artículo, evaluamos el efecto antiviral de seis extractos de plantas usadas por pueblos indígenas y afrocolombianos contra el SARS-CoV-2 in vitro. Metodología: El efecto antiviral de seis extractos preparados a partir de plantas usadas en medicina tradicional colombiana fue evaluado contra SARS-CoV-2 por medio de una estrategia de pre-post tratamiento en células Vero E6. Una vez se estableció la citotoxicidad por un ensayo de MTT, el efecto antiviral de estos extractos fue calculado basado en la reducción del título viral determinado por ensayo de plaqueo. Resultados: G. sepium inhibió SARS-CoV-2 en un 75.6\%, 56.8\%, 62.5\% y 40.0\% a $10 \mathrm{mg} / \mathrm{mL}, 8 \mathrm{mg} / \mathrm{mL}, 6 \mathrm{mg} / \mathrm{mL}$, and $2 \mathrm{mg} / \mathrm{mL}$, respectivamente. Mientras el extracto de Piper tuberculatum redujo el título viral en un $33.3 \%$ a $6 \mathrm{mg} / \mathrm{mL}$ luego de $48 \mathrm{~h}$ de tratamiento.

Palabras clave: SARS-CoV-2, Extracto de plantas, agente antiviral, etnobotánica.

\section{INTRODUCTION}

Emerging and re-emerging diseases pose a continuing challenge for global public health. Within these, respiratory diseases or syndromes caused by coronavirus have recently acquired relevance given the several outbreaks caused by this family of viruses since 2003 (1-3). However, currently the most important is the contagious disease COVID-19 (Corona Virus Infectious Disease 2019), first detected in December of 2019 in the province of Wuhan, China, and declared a pandemic by the World Health Organization (WHO) in March 2020 (4-7). This illness is caused by the infection with the new beta-coronavirus named Severe Acute Respiratory Syndrome Coronavirus 2 (SARS-CoV-2). A positivesense single-stranded RNA virus with a genome of approximately $30 \mathrm{~kb}$ with an untranslated structured region, which appears to be of zoonotic origin since it shares about $96 \%$ genetic homology with bat coronavirus and also high genomic homology, close to $80 \%$, with SARS-CoV, another beta-coronavirus described in 2002-2003 also in Asia $(2,8)$.

Symptoms caused by COVID-19 are unspecific, and the clinical presentation encompasses a wide range of manifestations, ranging from asymptomatic infections to severe pneumonia and death. The main symptoms of COVID-19 are fever, tiredness, and dry cough. Some patients may have shortness of breath, chills, muscle pain, loss of taste or smell, vomiting, diarrhea, and/or sore throat (4). Older people and people with pre-existing comorbidities such as high blood pressure (30.7\%), heart disease (11.9\%), lung disease (6\%), cancer, or diabetes (12-14\%) are more likely to develop a severe presentation (4). So far, the available vaccines to prevent infection do not reach $100 \%$ efficacy, and there is no specific antiviral treatment for SARS-CoV-2 infection; therefore, patient management focuses on symptomatic treatment (9).

This scenario makes clear the need to find new specific pharmacological and therapeutic alternatives against SARS-CoV-2 infection and opens a way to the exploration of a practice historically carried out by communities of Asia, Africa, and Latin America, such as the use of medicinal plants for diseases treatment $(10,11)$.

A medicinal plant is any plant that contains substances that can be used for therapeutic purposes; they can be prepared in different ways, including teas, infusions, vinegar extracts, or alcohol tinctures (12). Medicinal plants are used to treat a wide range of diseases and, in developing countries, represent an alternative to primary health care. It has been reported that approximately $80 \%$ of the world population uses medicinal plants for health purposes; It is also estimated that at least $50 \%$ of modern medicines contain one or more active ingredients originating from a plant (12).

Medicinal plants historically used in traditional Chinese medicine were utilized in about $91.5 \%$ of COVID-19 cases in China, showing encouraging results in improving the symptoms and reducing deterioration, mortality, and recurrence rates (13). In Colombia, medicinal plants play an important role in Afro-Colombian, mestizo, and indigenous territories treating different conditions, including COVID -19 (14, 15). Plants as Gliricidia sepium, Piper tuberculatum, Solanum arboreum, Moringa oleifera, and Bocconia frutescens have been used within indigenous people given their multiple properties. The antimicrobial properties of $G$. sepium has been reported previously $(16,17)$. More recently, 
Cordoba-Tovar et al. reported that this plant is one of the species with the highest use against COVID-19 by western Colombian people (18). P. tuberculatum and, $S$. arboreum are recognized and used mainly in the Colombian Pacific region for their antimicrobial, analgesic, and antipyretic properties against several diseases (14, 19-22), including COVID-19 despite the absence of scientific evidence. The potential of M. oleifera against SARS-CoV-2 has been explored recently by in silico approaches, finding flavonoid present on this plant showed good binding affinity, stable protein-ligand complexes, high binding energy, and similar binding poses in comparison with known SARS-CoV-2 Mpro inhibitor (23-25); its effect on COVID-19 associated coinfections has been explored as well (26). S. magellanicum is one of the most globally widespread mosses, traditionally used in Europe as an antiseptic and wound sterilization and was widely used during the first world war. Nowadays, traditional medicine uses this moss-like antibacterial and antiviral (27).

In this work, we set out to evaluate the antiviral activity against SARS-CoV-2 of six extracts produced from medicinal plants frequently used within the traditional medicine of the Pacific and other regions of Colombia to find possible therapeutic alternatives to face COVID-19.

\section{MATERIALS AND METHODS}

\subsection{Cells and virus}

Cercopithecus aethiops kidney cell line, Vero E6 was grown in Dulbecco's Modified Eagle Medium (DMEM, Sigma-Aldrich) supplemented with $2 \%$ heat-inactivated fetal bovine serum (FBS) (Gibco), $1 \%$ penicillin-streptomycin (Sigma-Aldrich), and $2 \mathrm{mM}$ L-glutamine (Sigma-Aldrich) at $37{ }^{\circ} \mathrm{C}$ with $5 \% \mathrm{CO}_{2}$. Vero E6 cell line was donated by Instituto Nacional de Salud (INS) (Bogotá, Colombia). Infections were carried out with a SARS-CoV-2 viral stock produced from a Colombian isolate an ancestral D614G strain (ID accession: EPI_ISL_536399), (hCoV-19/Colombia/ ANT-UdeA-200325-01/2020) (28).

\subsection{Colombian plants identification and registration}

Plant material and botanical samples were collected from some species used in traditional medicine by afro, indigenous, and farmers from departments of Chocó and Antioquia, to treat COVID-19 symptoms. The vouchers were deposited in the herbarium of the Universidad de Antioquia (HUA) with the collection numbers described in Table 1, Figure 1.

Table 1. List of plant species included in this study

\begin{tabular}{|l|l|l|c|}
\hline \multicolumn{1}{|c|}{ Species } & \multicolumn{1}{|c|}{ Common name } & \multicolumn{1}{c|}{ Family } & \multicolumn{1}{c|}{ Voucher } \\
\hline Gliricidia sepium (Jacq.) Kunth ex Walp. & Matarratón & Fabaceae & Alzate 5404 \\
\hline Piper tuberculatum Jacq. & Pipilongo or Santamaria & Piperaceae & Alzate 5405 \\
\hline Solanum arboreum Dunal & Sauco de monte or Sauco macho & Solanaceae & Alzate 5406 \\
\hline Moringa oleifera Lam. & Moringa or Ben & Moringaceae & Alzate 5464 \\
\hline Bocconia frutescens L. & Trompeto & Papaveraceae & Idarraga 3789 \\
\hline Sphagnum magellanicum Brid. & Esfagno & Sphagnaceae & Alzate 5463a \\
\hline
\end{tabular}

The herbal drugs were selected, and the extracts were prepared following the instructions used by the communities to obtain the effect against COVID-19 symptoms. 

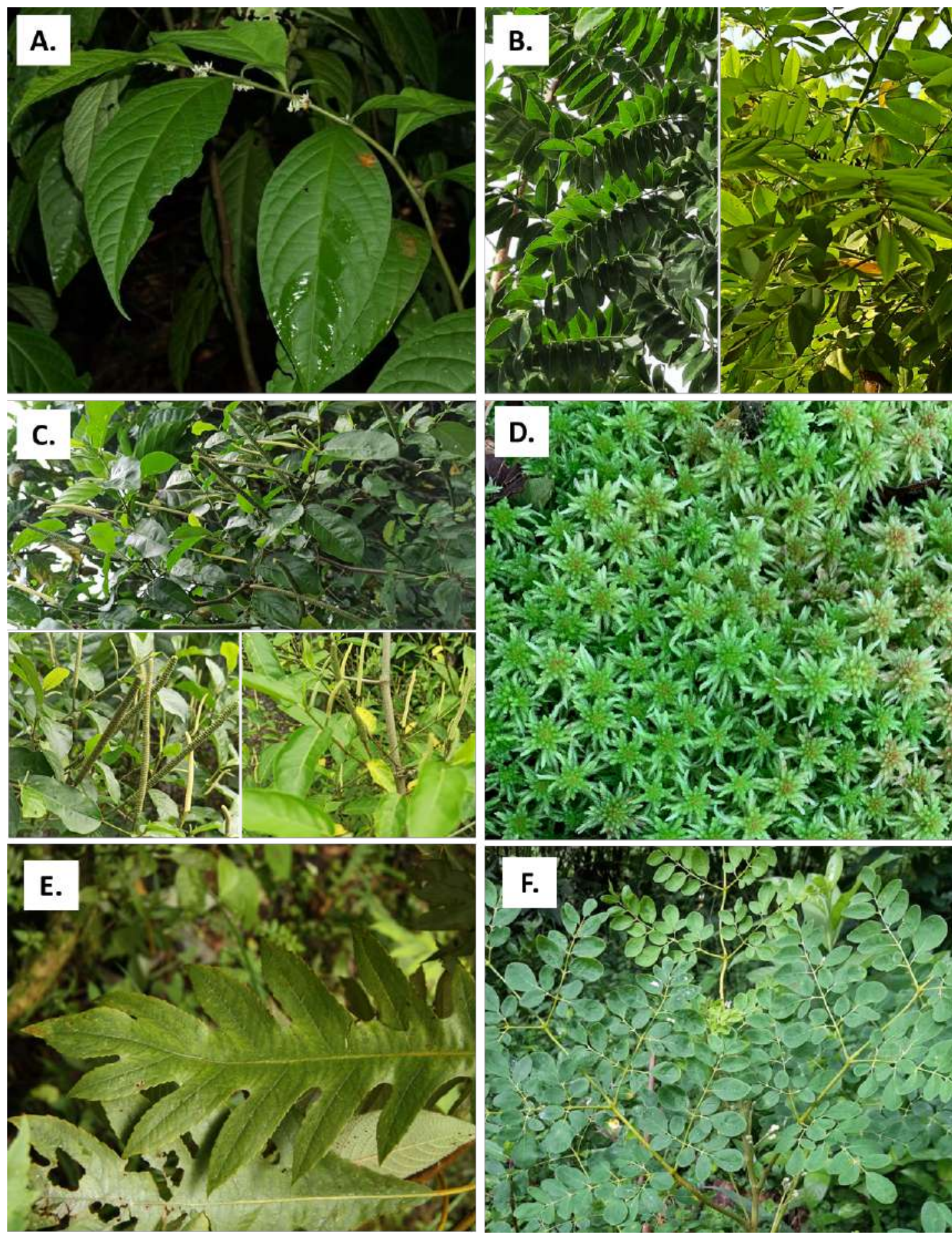

Figure 1. Photographs of plants used for extracts preparation.

A. Solanum arboreum (Taken from: STRI HERBARIUM. URL: https://biogeodb.stri.si.edu/bioinformatics/dfm/metas/view/43561). B. Gliricidia sepium. C. Piper tuberculatum. D. Sphagnum magellanicum. E. Bocconia frutescens. F. Moringa oleifera.

\subsection{Plant extracts preparation}

Each fresh plant was extracted with $50 \mathrm{~mL}$ solvent (reagent grade) or distilled water at room temperature $\left(20^{\circ} \mathrm{C}\right)$. The samples were macerated by 10 minutes and filtered using 595 Whatman ${ }^{\circledR}$ cellulose filters, exhibiting particle retention levels of 7-12 $\mu \mathrm{m}$. Then, the filtrates were transferred into glass bottles. The concentrations of the extracts were around $120 \mathrm{mg} / \mathrm{mL}$. All extracts were stored at $4{ }^{\circ} \mathrm{C}$ until use. More detailed information about extract preparation can be found in Table 2. 
Table 2. Plant species, herbal drugs and solvents used for the extract preparations.

\begin{tabular}{|l|l|c|c|c|}
\hline \multicolumn{1}{|c|}{ Species } & Herbal drug & Weight $(\mathbf{g})$ & Solvent & Volume (mL) \\
\hline Moringa oleifera & Leaf & 6.00662 & Water & 50.0 \\
\hline Bocconia frutescens & Leaft and stem & 6.04500 & $\mathrm{HCl} 5 \%$ & 50.0 \\
\hline Piper tuberculatum & Inflorescence & 6.10450 & Water & 50.0 \\
\hline Gliricidia sepium & Leaf & 6.27841 & Water & 50.0 \\
\hline Solanum arboreum & Leaf & 6.22018 & Water & 50.0 \\
\hline Sphagnum magellanicum & Whole plant & 6.00213 & $\mathrm{HCl} 5 \%$ & 50.0 \\
\hline
\end{tabular}

\subsection{Cytotoxicity assay}

The cytotoxicity of plant extracts was evaluated on Vero E6 cells by an MTT (3-[4,5-dimethylthiazol-2yl]-2,5 diphenyl tetrazolium bromide) assay. Briefly, Vero E6 cells were seeded in 96-well plates at a cell density of $1.0 \times 10^{4}$ cells/well in DMEM supplemented with $2 \%$ FBS. Then, the plates were incubated for $24 \mathrm{~h}$ at $37{ }^{\circ} \mathrm{C}$ with $5 \% \mathrm{CO}_{2}$. After incubation, $150 \mu \mathrm{L} /$ well of plant extracts dilutions were added to each well in quadruplicate and incubated for $48 \mathrm{~h}$, at $37{ }^{\circ} \mathrm{C}$ with $5 \% \mathrm{CO}_{2}$. After incubation, the supernatants were removed, and cells were washed twice with Phosphate Buffered Saline (PBS) (Lonza) before adding $30 \mu \mathrm{L} /$ well of MTT $(2 \mathrm{mg} / \mathrm{mL})$. Following MTT addition, plates were incubated for $2 \mathrm{~h}$ at $37^{\circ} \mathrm{C}$, with $5 \% \mathrm{CO}_{2}$, protected from light. Finally, formazan crystals were dissolved by adding $100 \mu \mathrm{L} /$ well of pure DMSO (29).

Plates were read at $570 \mathrm{~nm}$ using a Multiskan GO spectrophotometer (Thermo-Scientific). The average absorbance of untreated cells was used as a viability control. The cell viability of each treated well was calculated based on the viability control. Concentrations with cell viability $>85 \%$ after treatment was considered non-cytotoxic. For the MTT assay, two independent experiments were performed $(n=8)$.

\subsection{Evaluation of the antiviral activity against SARS-CoV-2}

The antiviral activity of plant extracts was evaluated by a pre-post-infection treatment strategy, where the cells are treated after and before $1 \mathrm{~h}$ of virus adsorption. Briefly, Vero E6 cells were seeded in 96-well plates $\left(1.0 \times 10^{4}\right.$ cells/well) and incubated for $24 \mathrm{~h}$, at $37{ }^{\circ} \mathrm{C}$ with $5 \% \mathrm{CO}_{2}$. Then, plants extract dilutions selected based on cytotoxic assay were prepared and added to the cell monolayers $(50 \mu \mathrm{L} /$ well) for $1 \mathrm{~h}$. After pre-treatment, the extract was removed, and the virus inoculum was added at a multiplicity of infection (MOI) of 0.01 in $50 \mu \mathrm{L} /$ well of DMEM supplemented with $2 \%$ FBS. After $1 \mathrm{~h}$ of virus adsorption at $37^{\circ} \mathrm{C}$, the inoculum was removed and replaced by $150 \mu \mathrm{L} /$ well of the same pre-treatment dilutions. Finally, the plates were incubated for 48 h at $37^{\circ} \mathrm{C}$ with a $5 \% \mathrm{CO}_{2}$ atmosphere. After $48 \mathrm{~h}$ of incubation, the supernatants were harvested and stored at $-80^{\circ} \mathrm{C}$ for viral titration by plaque assay. Chloroquine at $100 \mu \mathrm{g} / \mathrm{mL}$ was included as positive inhibition control. The supernatant of infected cells without treatment was used as uninfected control. Two independent experiments with four replicate each were performed $(n=8)$.

\subsection{SARS-CoV-2 quantification by Plaque assay}

The antiviral activity of Colombian plant extracts was determined by reducing the infectious particles of SARS-CoV-2 in supernatants of treated cells by plaque assay. Briefly, $1.2 \times 10^{5}$ Vero E6 cells/well were seeded in 24-well plates for $24 \mathrm{~h}$, at $37^{\circ} \mathrm{C}$, with $5 \% \mathrm{CO}_{2}$. Subsequently, tenfold serial dilutions of the supernatants obtained from the antiviral assay $(200 \mu \mathrm{L} /$ well) were added to cell monolayers and incubated for $1 \mathrm{~h}$ at $37{ }^{\circ} \mathrm{C}$ with $5 \% \mathrm{CO}_{2}$. Then, the viral inoculum was removed and replaced by $1 \mathrm{~mL}$ of semi-solid medium (1.5\% Carboxymethylcellulose in DMEM 1X with $2 \%$ FBS and $1 \%$ Penicillin-Streptomycin). Cells were incubated for 3 days at $37{ }^{\circ} \mathrm{C}$, with $5 \% \mathrm{CO}_{2}$. Finally, monolayers were washed twice with PBS, fixed/stained with 4 $\%$ Formaldehyde/ 1 \% Crystal violet solution, and viral plaques were counted.

The difference between the viral titer after treatment and the untreated control was expressed as inhibition percentage. Two independent experiments were performed $(n=4)$ with two replicates each. 


\subsection{Statistical analysis}

All data were analyzed with GraphPad Prism (La Jolla, CA, USA). Data were presented as mean \pm SEM. Statistical differences were evaluated by Student's t-test or Mann-Whitney $U$ test based on Shapiro Wilk normality test. A p-value $\leq 0.05$ was considered significant, with ${ }^{*} p \leq 0.05$ and ${ }^{\star *} p \leq 0.01$.

\section{RESULTS}

\subsection{Cytotoxicity of plant extracts on VeroE6.}

For the cytotoxic assay, S. arboreum, G. sepium and $P$. tuberculatum extracts were evaluated from $10 \mathrm{mg} / \mathrm{mL}$ to $2 \mathrm{mg} / \mathrm{mL}$ using double serial dilutions. After $48 \mathrm{~h}$ treatment, Vero E6 monolayers exhibited viabilities lower than $85 \%$ for $S$. arboreum and $P$. tuberculatum extracts at $10 \mathrm{mg} / \mathrm{mL}$ and $8 \mathrm{mg} / \mathrm{mL}$; while at $6 \mathrm{mg} / \mathrm{mL}$, these plant extracts showed viabilities of $89.1 \%$ and $88.1 \%$, respectively. $A n I C_{50}$ of $28.8 \mathrm{mg} / \mathrm{mL}$ and $12.23 \mathrm{mg} / \mathrm{mL}$ were calculated for these extracts, respectively. G. sepium extract treatment showed viabilities higher than $85 \%$ at all evaluated concentrations ( $\mathrm{IC}_{50}$ was not calculated).
Sphagnum magellanicum, $B$. frutescens and M. oleifera extracts were cytotoxic at $2 \mathrm{mg} / \mathrm{mL}$ (data not shown). For this reason, these extracts were evaluated at lower concentrations. Vero E6 monolayers exhibit a viability of $84.86 \%$ at $1 \mathrm{mg} / \mathrm{mL}$ with S. magellanicum treatment while $93.1 \%$ at $0.8 \mathrm{mg} / \mathrm{mL}$, S. magellanicum extract shown an $I_{50}$ of $1.2 \mathrm{mg} / \mathrm{mL}$. For $B$. frutescens extract, viabilities of $28.6 \%$ and $80.7 \%$ were observed at $0.8 \mathrm{mg} / \mathrm{mL}$ and $0.6 \mathrm{mg} / \mathrm{mL}$, respectively, while $88.4 \%$ at $0.4 \mathrm{mg} / \mathrm{mL}$ to an $\mathrm{IC}_{50}$ of $0.71 \mathrm{mg} / \mathrm{mL}$. Finally, $M$. oleifera extract exhibited viabilities around $99.2 \%$ at $0.6 \mathrm{mg} / \mathrm{mL}$, while $75.2 \%$ and $48.7 \%$ at $0.8 \mathrm{mg} / \mathrm{mL}$ and $1 \mathrm{mg} /$ $\mathrm{mL}$ respectively for an $\mathrm{IC}_{50}$ of $0.95 \mathrm{mg} / \mathrm{mL}$.

Based on the results of the cytotoxic assay, $S$. arboreum and $P$. tuberculatum extracts were evaluated from $6 \mathrm{mg} / \mathrm{mL}$ and $G$. sepium from 10 $\mathrm{mg} / \mathrm{mL}$ for antiviral assay. On the other hand, $S$. magellanicum, $M$. oleifera and $B$. frutescens extracts were evaluated from $0.8 \mathrm{mg} / \mathrm{mL}, 0.6 \mathrm{mg} / \mathrm{mL}$, and 0.4 $\mathrm{mg} / \mathrm{mL}$, respectively.

B.
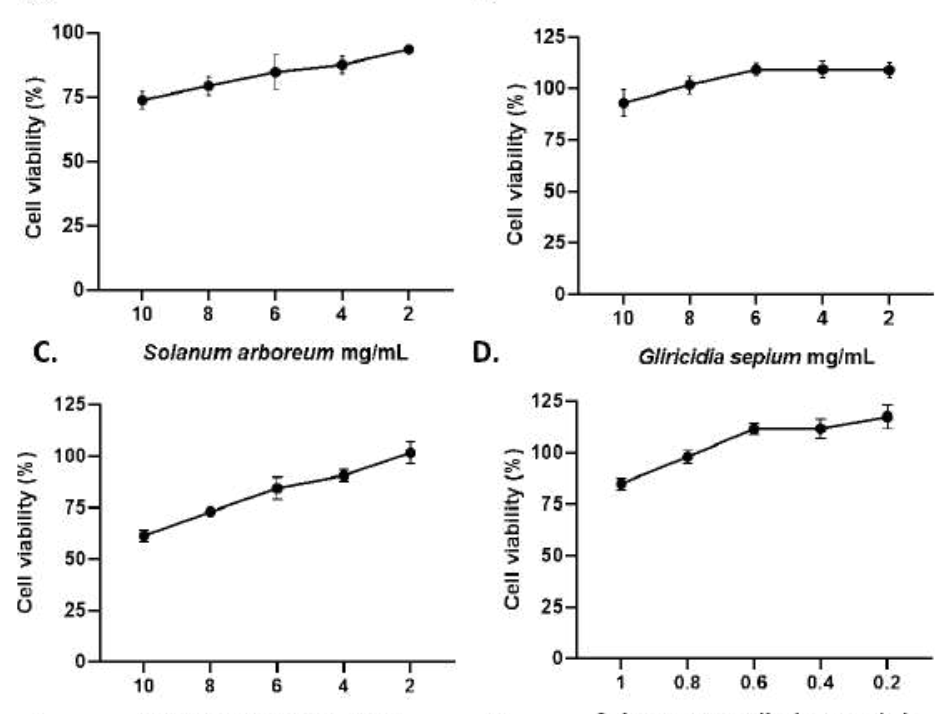

E. Piper tuberculatum $\mathrm{mg} / \mathrm{mL}$

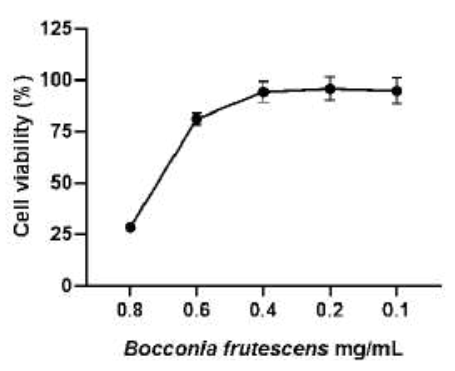

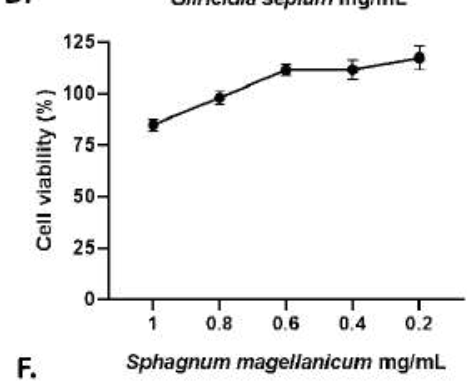

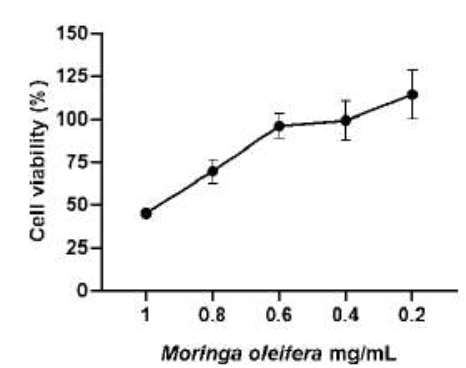

Figure 2. Cytotoxicity of plant extracts on Vero E6. The graph shows the viability of Vero E6 monolayers after $48 \mathrm{~h}$ treatment with plant extracts at five different concentrations. Data are shown as mean \pm SEM. Two different experiments were done with four replicas each $(n=8)$ 


\subsection{G. sepium and $P$. tuberculatum extracts exhibit antiviral activity against SARS-CoV-2.}

After $48 \mathrm{~h}$ of pre-post treatment strategy, G. sepium and $P$. tuberculatum extracts treatment resulted in a reduction of SARS-CoV-2 viral titer on Vero E6 supernatants compared to untreated control. $G$. sepium treatment exhibited a reduction of $75.6 \%$ $(p=0.009), 56.88 \%(p=0.009), 62.50 \%(p=0.009)$, and $40.0 \%(p=0.009)$ at $10 \mathrm{mg} / \mathrm{mL}, 8 \mathrm{mg} / \mathrm{mL}, 6 \mathrm{mg} /$ $\mathrm{mL}$, and $4 \mathrm{mg} / \mathrm{mL}$ (Figure 3 ). The supernatant of $P$. tuberculatum treated cells exhibited a reduction of $33.3 \%(p=0.004)$ in SARS-CoV-2 titer compared to the supernatant of untreated cells at $6 \mathrm{mg} / \mathrm{mL}$.
Solanum arboreum, S. magellanicum and B. frutescens extracts treatment showed no antiviral activity at any evaluated concentration with a prepost treatment strategy; instead an increase in viral titer was observed at $6 \mathrm{mg} / \mathrm{mL}$ for $S$. arboreum, 0.6 and $0.4 \mathrm{mg} / \mathrm{mL}$ for $S$. magellanicum, and from 0.2 to $0.05 \mathrm{mg} / \mathrm{mL}$ for $B$. frutescens. No differences in viral titer were observed after $M$. oleifera treatment after $48 \mathrm{~h}$ at any evaluated concentration (Figure 3 ).

Chloroquine at $100 \mu \mathrm{M}$ was used as inhibition control showing a reduction of $100 \%$ in SARS-CoV-2 viral titer (Figure 3).
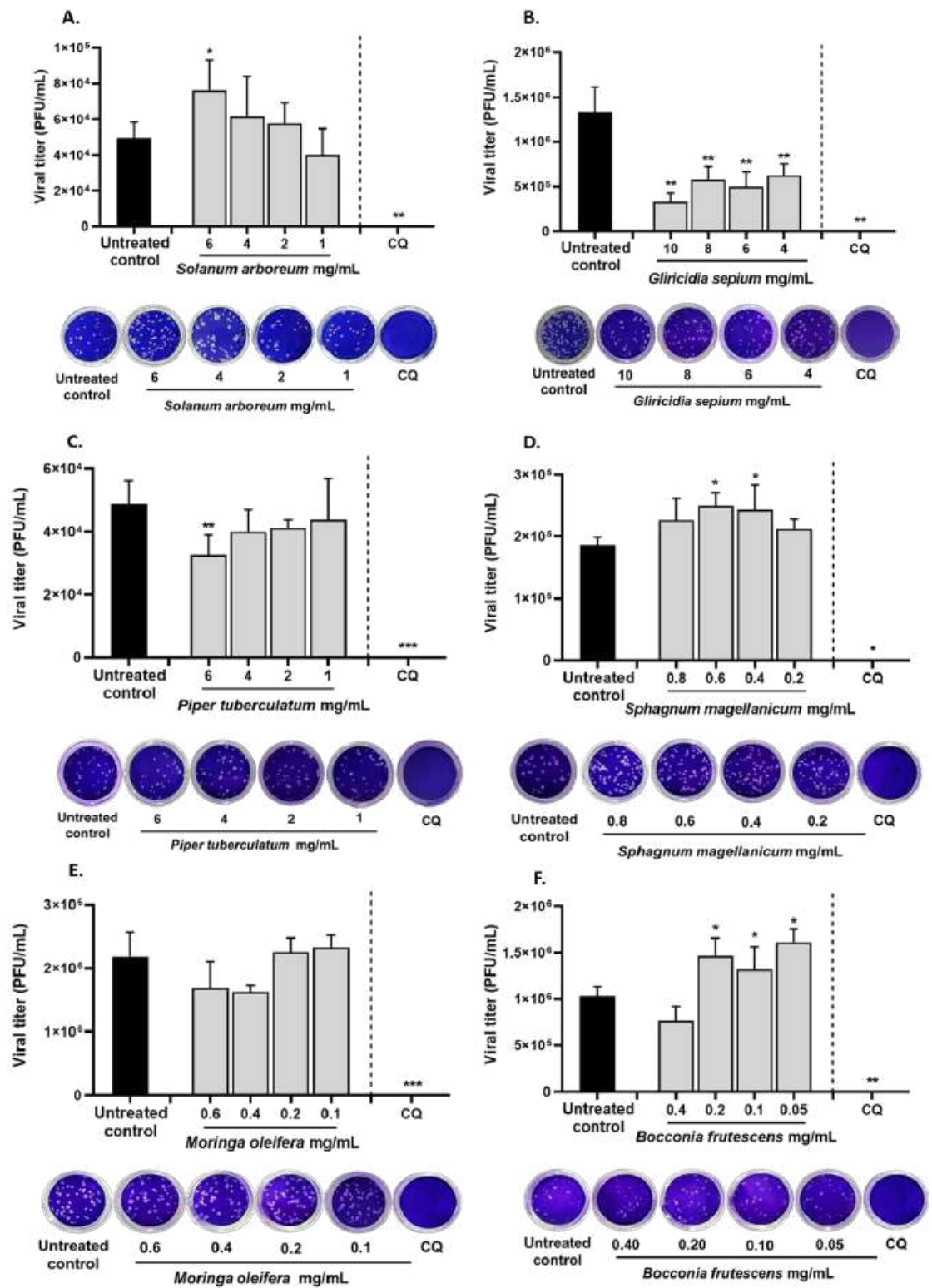

Figure 3. Antiviral activity of plant extracts against SARS-CoV-2 on Vero E6. The graph shows the titers of SARS-CoV-2 in supernatants of VeroE6 monolayers after $48 \mathrm{~h}$ treatment with plant extracts together with a representative figure of the plaque assay on Vero E6 after five days of incubation. Data are shown as mean \pm SEM. Two different experiments were done with two replicas each ( $n=4)$. 


\section{DISCUSSION}

This article evaluates the antiviral activity of six extracts prepared from six plants used for indigenous people from the Colombian pacific and Andean regions to treat SARS-CoV-2 infection and COVID-19 related symptoms to bring light about the efficacy of these traditional treatments widely used in our territory.

Our results showed that $G$. sepium, has antiviral effect against SARS-CoV-2 in vitro. The biological activity of $G$. sepium against several organisms has been widely studied. Leaf extracts of this plant showed larvicidal activities against Anopheles stephansi, Aedes aegypti, and Culex quinquefasciatus (30). Leaves of Gliricidia sepium also have antimicrobial activity against bacteria and nematodes (31). On the other hand, G. sepium antiviral activity has been slightly explored. In 2010 Hernández Ramírez et al. reported $100 \%$ remission of symptoms and normal leukocyte and platelet number in a small group of patients with dengue virus after administration of the leaf extract (32). However, there are no other reports of $G$. sepium activity against viruses. Based on our results, $G$. sepium extract reduces SARSCoV-2 viral titer at all evaluated concentrations after $48 \mathrm{~h}$ treatment.

Given the wide range of $G$. sepium biological activity studies against different microorganisms, the presence of compounds with biological activity has been previously reported. The glycosides, alkaloids, saponins, and flavonoids present in G. sepium extracts have been proposed as responsible for the antibacterial, antioxidant and anti-inflammatory properties (31). Among those compounds, saponins and flavonoids have inhibitory potential against SARS-CoV-2 demonstrated by in silico analysis $(33,34)$.

In 2021, Fakhar et al. analyzed in silico the interaction of several anthocyanin derivatives with SARS-CoV-2 Mpro (Main protein), obtaining better docking score (DS) values (from $-9.58 \mathrm{kcal} / \mathrm{mol}$ to $-12.37 \mathrm{kcal} / \mathrm{mol}$ ) than N3-I, a native inhibitor of Mpro $(-9.47 \mathrm{kcal} / \mathrm{mol})$ (33). Similar results were reported by Falade et al. in which saponins obtained DS around $-8.0 \mathrm{kcal} / \mathrm{mol}$ improving the values for N3-I $(-7.3 \mathrm{kcal} / \mathrm{mol})$ and with better pharmacokinetics and bioavailability compared to Remdesivir, the only approved drug to COVID-19 treatment $(34,35)$.

The potential of plants belonging to the Piper genus as a source of new natural and bioactive compounds has been reviewed by several authors
$(36,37)$. The occurrence of alkamides, piperamides, kavalactones, and benzoic acid derivatives has been reported for plants of the Piper genus (36, 38). Likewise, several biological activities, including biocidal activity against bacteria like Mycobacterium tuberculosis, activities against various protozoa like Leishmania, Plasmodium, and Trypanosoma $(39,40)$, and antiviral activity against West Nile Virus and Human immuno deficienty virus resistant strains $(41,42)$. Among those compounds, alkamides and piperamides containing amides and aromatic groups similar to remdesivir, an approved drug for COVID-19, can exert a potential inhibition of SARSCoV-2, given the interaction of these structures with Mpro, RdRp (RNA dependent RNA polymerase), and ACE2 (angiotensin converting enzyme) (43-45).

The interaction of Piper compounds with SARSCoV-2 viral proteins has been evaluated in silico (35). Gutierrez-Villagomez et al. reported that alkamides and dimeric piperamides from Piper species exhibited a high binding affinity for two SARS-CoV-2 proteins (Mpro and RdRp). The complex formed between pipercyclobutanamide $B$ and Mpro showed a DS of $-7.83 \mathrm{kcal} / \mathrm{mol}$, like the values obtained by N3-I (-7.35 $\mathrm{kcal} / \mathrm{mol})$ (35). Together with these docking results, the ADME profile indicated that dimeric piperamides have drug-likeness potential (35). This evidence and the fact that $P$. tuberculatum treatment exhibited a reduction of $33.33 \%$ in SARS-CoV-2 viral titer in vitro suggest that $P$. tuberculatum and other Piper species can represent a target for anti-SARS-CoV-2 drug research.

The results obtained for $S$. arboreum, $S$. magellanicum, and $B$. frutescens treatment indicates an increase of viral titer; this result could be due to compounds present in the extract that at those concentrations can promote cell proliferation or regulation of metabolic pathways affecting the expression of viral receptors or proteins synthesis, that is the case of $S$. magellanicum extract which has been reported to be rich in amino acids affecting the protein synthesis; however more studies are needed to identify particular molecules involved in this response $(46,47)$

The evidence presented in this article shows the potential of the ethnobotanical approach in the search for natural compounds with biological activities, optimizing the search of natural candidates for antiviral screening. We also previous evidence of its potential as anti-SARS-CoV-2 alternatives, exhibiting Mpro as an important target to consider 
for further research. However, further studies are necessary to identify the specific molecules with antiviral activity.

\section{CONCLUSION}

Gliricidia sepium and P. tuberculatum have been widely used by Colombian indigenous and afro people to treat different diseases. Previous studies have shown their antiviral effect against other RNA viruses; besides, recently in silico approaches have shown their potential as antiviral agents against SARS-CoV-2. This article presents evidence of the antiviral effect of $G$. sepium and $P$. tuberculatum extracts reducing in vitro the titer of SARS-CoV-2 after $48 \mathrm{~h}$ treatment. This evidence demonstrates the potential of these plants as a therapeutic alternative against SARS-CoV-2 infection and the importance of future studies to elucidate molecules with antiviral activity, mechanisms of action, and their potential use for the treatment of COVID-19.

\section{CONFLICTS OF INTEREST}

The authors declare that they have no known conflicts of interest or personal relationships that could have appeared to influence the work reported in this paper.

\section{FUNDING STATEMENT}

This study was financed by Universidad de Antioquia, and Universidad Cooperativa de Colombia, Sede Medellín; BPIN 2020000100131- SGR

\section{AUTHOR CONTRIBUTION}

Lizdany Flórez-Álvarez -LFA, Jahnnyer MartínezMoreno -JMM, María I. Zapata-Cardona- MZC, Elkin Galeano - EG, Fernando Alzate-Guarin -FAG, Wildeman Zapata- WZ

Conceptualization, LFA, JMM, MZC, WZ.; Plant material obtention, EG, FAG, JMM; Methodology, LFA, MZC, WZ, EG, FAG.; Formal Analysis, LFA, and MZC; Investigation, JMM, LFA, and MZC.; Resources, EG, FAG, WZ; Data Curation, EG, FAG, WZ; Writing - Original Draft Preparation, JMM, LFA.; Writing Review \& Editing, JMM, LFA, EG, FAG, WZ. Project Administration, WZ; Funding Acquisition, WZ".

\section{REFERENCES}

1. Hui DS, E IA, Madani TA, Ntoumi F, Kock R, Dar O, et al. The continuing 2019-nCoV epidemic threat of novel coronaviruses to global health - The latest 2019 novel coronavirus outbreak in Wuhan, China. Int J Infect Dis. 2020;91:264-6. https://doi. org/10.1016/j.ijid.2020.01.009

2. Kaul D. An overview of coronaviruses including the SARS-2 coronavirus - Molecular biology, epidemiology and clinical implications. Curr Med Res Pract. 2020;10(2):54-64. https://doi. org/10.1016/j.cmrp.2020.04.001

3. Parr J. Pneumonia in China: lack of information raises concerns among Hong Kong health workers. BMJ. 2020;368:m56. https:// doi.org/10.1136/bmj.m56

4. Huang D, Lian X, Song F, Ma H, Lian Z, Liang Y, et al. Clinical features of severe patients infected with 2019 novel coronavirus: a systematic review and meta-analysis. Ann Transl Med. 2020;8(9):576. https://doi.org/10.21037/atm-20-2124

5. Balkhair AA. COVID-19 Pandemic: A New Chapter in the History of Infectious Diseases. Oman Med J. 2020;35(2):e123. https://doi. org/10.5001/omj.2020.41

6. Wu F, Zhao S, Yu B, Chen YM, Wang W, Song ZG, et al. A new coronavirus associated with human respiratory disease in China. Nature. 2020;579(7798):265-9. https://doi.org/10.1038/s41586020-2008-3

7. WHO. WHO Coronavirus (COVID-19) Dashboard: WHO; 2021 [Available from: https://covid19.who.int/]

8. Peng M. Outbreak of COVID-19: An emerging global pandemic threat. Biomed Pharmacother. 2020;129:110499. https://doi. org/10.1016/j.biopha.2020.110499

9. Paltiel AD, Schwartz JL, Zheng A, Walensky RP. Clinical Outcomes Of A COVID-19 Vaccine: Implementation Over Efficacy. Health Aff (Millwood). 2021;40(1):42-52. https://doi.org/10.1377/ hlthaff.2020.02054

10. Lee DYW, Li OY, Liu J, Efferth T. Traditional Chinese herbal medicine at the forefront battle against COVID-19: Clinical experience and scientific basis. Phytomedicine. 2021;80:153337. https://doi.org/10.1016/j.phymed.2020.153337

11. Geck MS, Cristians S, Berger-Gonzalez M, Casu L, Heinrich M, Leonti M. Traditional Herbal Medicine in Mesoamerica: Toward Its Evidence Base for Improving Universal Health Coverage. Front Pharmacol. 2020;11:1160. https://doi.org/10.3389/ fphar.2020.01160

12. Sofowora A, Ogunbodede E, Onayade A. The role and place of medicinal plants in the strategies for disease prevention. Afr J Tradit Complement Altern Med. 2013;10(5):210-29. https://doi. org/10.4314/ajtcam.v10i5.2

13. Luo L, Jiang J, Wang C, Fitzgerald M, Hu W, Zhou Y, et al. Analysis on herbal medicines utilized for treatment of COVID-19. Acta Pharm Sin B. 2020;10(7):1192-204. https://doi.org/10.1016/j. apsb.2020.05.007

14. Valoyes DC, Palacios Palacios L. Patrones de uso de las plantas medicinales en el Chocó y Cauca (Colombia). Ciencia en Desarrollo. 2020;11(2):85-96. https://doi.org/10.19053/01217488. v11.n2.2020.10583

15. Garzón Garzón Lp. CONOCIMIENTO TRADICIONAL SOBRE LAS PLANTAS MEDICINALES DE YARUMO (Cecropia sciadophylla), CARAMBOLO (Averrhoa carambola) Y UÑA DE GATO (Uncaria tomentosa) EN EL RESGUARDO INDÍGENA DE MACEDONIA AMAZONAS. Luna Azul. 2016(43):386-414 
16. Rojas JJ, Ochoa VJ, Ocampo SA, Munoz JF. Screening for antimicrobial activity of ten medicinal plants used in Colombian folkloric medicine: a possible alternative in the treatment of nonnosocomial infections. BMC Complement Altern Med. 2006;6:2. https://doi.org/10.1186/1472-6882-6-2

17. Neethu S K, Neethu S. In vitro antibacterial activity and phytochemical analysis of Gliricidia sepium (L.) leaf extracts. Journal of Pharmacognosy and Phytochemistry. 2016;5(2):131-3

18. Cordoba-Tovar L, Ríos-Geovo V, Largacha-Viveros MF, SalasMoreno M, Marrugo-Negrete JL, Ramos PA, et al. Cultural belief and medicinal plants in treating COVID 19 patients of Western Colombia. Acta Ecologica Sinica. 2021. https://doi.org/https:// doi.org/10.1016/j.chnaes.2021.10.011

19. Perea Pandales K. Plantas medicinales reconocidas por dos comunidades del Chocó, Colombia, en el tratamiento del reumatismo. Revista Biodiversidad Neotropical. 2017;7(2):67-75

20. Salas JJ, Moncada B, Ledezma E. Municipio Medio Atrato, Departamento Chocó, COLOMBIA PLANTAS MEDICINALES del Corregimiento Bocas de Bebará: Universidad Tecnológica del Chocó Diego Luis Córdoba. 2014.

21. Dos Santos Sales V, Monteiro AB, Delmondes GA, do Nascimento EP, Sobreira Dantas Nobrega de Figueiredo FR, de Souza Rodrigues CK, et al. Antiparasitic Activity and Essential Oil Chemical Analysis of the Piper Tuberculatum Jacq Fruit. Iran J Pharm Res. 2018;17(1):268-75

22. de Araújo-Júnior J, Ribeiro EA, da Silva SA, da Costa CD. Cardiovascular effects of two amides (Piperine and Piperdardine) isolated from Piper tuberculatum Jacq. Emir J Food Agric 2011;23(3):265-74

23. Sen D, Bhaumik S, Debnath P, Debnath S. Potentiality of Moringa oleifera against SARS-CoV-2: identified by a rational computer aided drug design method. J Biomol Struct Dyn. 2021:1-18. https://doi.org/10.1080/07391102.2021.1898475

24. Sivani BM, Venkatesh P, Murthy TPK, Kumar SB. In silico screening of antiviral compounds from Moringa oleifera for inhibition of SARS-CoV-2 main protease. Current Research in Green and Sustainable Chemistry. 2021;4:100202. https://doi.org/https:// doi.org/10.1016/j.crgsc.2021.100202

25. Ullah A, Ullah K. Inhibition of SARS-CoV-2 3CL Mpro by Natural and Synthetic Inhibitors: Potential Implication for Vaccine Production Against COVID-19. Frontiers in Molecular Biosciences. 2021;8(211). https://doi.org/10.3389/fmolb.2021.640819

26. Tiwari Pandey A, Pandey I, Zamboni P, Gemmati D, Kanase A Singh AV, et al. Traditional Herbal Remedies with a Multifunctional Therapeutic Approach as an Implication in COVID-19 Associated Co-Infections. Coatings. 2020;10(8):761. https://doi.org/10.3390/ coatings10080761

27. Crespin Cruz YL, Rojas Morante KE. Delimitación de la actividad antibacterial del sphagnum magellanicum. Universidad de Guayaquil, Facultad de Ingeniería Química; 2019.

28. Diaz FJ, Aguilar-Jimenez W, Florez-Alvarez L, Valencia G, LaitonDonato K, Franco-Munoz C, et al. Isolation and characterization of an early SARS-CoV-2 isolate from the 2020 epidemic in Medellin, Colombia. Biomedica. 2020;40(Supl. 2):148-58. https://doi. org/10.7705/biomedica.5834

29. Yepes-Perez AF, Herrera-Calderon O, Oliveros CA, Florez-Alvarez L, Zapata-Cardona MI, Yepes L, et al. The Hydroalcoholic Extract of Uncaria tomentosa (Cat's Claw) Inhibits the Infection of Severe Acute Respiratory Syndrome Coronavirus 2 (SARS-CoV-2) In Vitro. Evid Based Complement Alternat Med. 2021;2021:6679761. https://doi.org/10.1155/2021/6679761

30. Sharma N, Qadry JS, Subramanium B, Verghese T, Rahman SJ, Sharma SK, et al. Larvicidal activity of Gliricidia sepium against mosquito larvae of Anopheles stephansi, Aedes aegypti and
Culex quinquefasciatus. Pharm Biol. 1998;36(1):3-7. https://doi. org/DOI 10.1076/phbi.36.1.3.4616

31. T.Jasmine, Sundaram RM, M.Poojitha, G.Swarnalatha, J.Padmaja, kumar MR, et al. Medicinal properties of Gliricidia sepium: A REVIEW. International Journal of Current Pharmaceutical \& Clinical Research. 2017;7(1):35-9

32. Hernández Ramírez I, Hernan GT, H, López Muñoz N, . El matarratón: potente agente antiviral. Evaluación del efecto terapéutico de Gliciridia sepium en el tratamiento del dengue clásico, Tumaco, Nariño, 2007-2008. Revista Nacional de Investigación. 2010;8(13)

33. Fakhar Z, Faramarzi B, Pacifico S, Faramarzi S. Anthocyanin derivatives as potent inhibitors of SARS-CoV-2 main protease: An in-silico perspective of therapeutic targets against COVID-19 pandemic. J Biomol Struct Dyn. 2020:1-13. https://doi.org/10.10 80/07391102.2020.1801510

34. Falade VA, Adelusi TI, Adedotun IO, Abdul-Hammed M, Lawal TA, Agboluaje SA. In silico investigation of saponins and tannins as potential inhibitors of SARS-CoV-2 main protease (M(pro)). In Silico Pharmacol. 2021;9(1):9. https://doi.org/10.1007/s40203020-00071-w

35. Gutierrez-Villagomez JM, Campos-Garcia T, Molina-Torres J, Lopez MG, Vazquez-Martinez J. Alkamides and Piperamides as Potential Antivirals against the Severe Acute Respiratory Syndrome Coronavirus 2 (SARS-CoV-2). J Phys Chem Lett. 2020;11(19):8008-16. https://doi.org/10.1021/acs.jpclett.0c01685

36. Cáceres A, Kato MJ. Importance of a multidisciplinary evaluation of Piper genus for development of new natural products in Latin America. International Journal of Phytocosmetics and Natural Ingredients. 2014;1(1):4-.https://doi.org/10.15171/ijpni.2014.04

37. Chaveerach A, Mokkamul P, Sudmoon R, Tanee T. Ethnobotany of the Genus Piper (Piperaceae) in Thailand. Ethnobotany Research and Applications. 2006;4:223. https://doi.org/10.17348/ era.4.0.223-231

38. Silva ML, Coimbra HS, Pereira AC, Almeida VA, Lima TC, Costa $E S$, et al. Evaluation of piper cubeba extract, (-)-cubebin and its semi-synthetic derivatives against oral pathogens. Phytother Res. 2007;21(5):420-2. https://doi.org/10.1002/ptr.2088

39. Diaz LE, Munoz DR, Prieto RE, Cuervo SA, Gonzalez DL, Guzman JD, et al. Antioxidant, antitubercular and cytotoxic activities of Piper imperiale. Molecules. 2012;17(4):4142-57. https://doi. org/10.3390/molecules17044142

40. Flores N, Jimenez IA, Gimenez A, Ruiz G, Gutierrez D, Bourdy G, et al. Antiparasitic activity of prenylated benzoic acid derivatives from Piper species. Phytochemistry. 2009;70(5):621-7. https://doi. org/10.1016/j.phytochem.2009.03.010

41. Zhu M, Zhou H, Ma L, Dong B, Zhou J, Zhang G, et al. Design and evaluation of novel piperidine HIV-1 protease inhibitors with potency against DRV-resistant variants. Eur J Med Chem. 2021;220:113450. https://doi.org/10.1016/j.ejmech.2021.113450

42. Radice M, Pietrantoni A, Guerrini A, Tacchini M, Sacchetti G, Chiurato $M$, et al. Inhibitory effect of Ocotea quixos (Lam.) Kosterm. and Piper aduncum L. essential oils from Ecuador on West Nile virus infection. Plant Biosystems - An International Journal Dealing with all Aspects of Plant Biology. 2018;153(3):34451. https://doi.org/10.1080/11263504.2018.1478902

43. Zhang L, Lin D, Sun X, Curth U, Drosten C, Sauerhering L, et al. Crystal structure of SARS-CoV-2 main protease provides a basis for design of improved alpha-ketoamide inhibitors. Science. 2020;368(6489):409-12. https://doi.org/10.1126/science.abb3405

44. Wang F, Chen C, Tan W, Yang K, Yang H. Structure of Main Protease from Human Coronavirus NL63: Insights for Wide Spectrum Anti-Coronavirus Drug Design. Sci Rep. 2016;6:22677. https://doi.org/10.1038/srep22677 
45. Elfiky AA. Ribavirin, Remdesivir, Sofosbuvir, Galidesivir, and Tenofovir against SARS-CoV-2 RNA dependent RNA polymerase (RdRp): A molecular docking study. Life Sci. 2020;253:117592. https://doi.org/10.1016/j.lfs.2020.117592

46. Tabatabaei FS, Moezizadeh M, Javand F. Effects of extracts of Salvadora persica on proliferation and viability of human dental pulp stem cells. J Conserv Dent. 2015;18(4):315-20. https://doi. org/10.4103/0972-0707.159740
47. Klavina L, Springe G, Nikolajeva V, Martsinkevich I, Nakurte I, Dzabijeva D, et al. Chemical Composition Analysis, Antimicrobial Activity and Cytotoxicity Screening of Moss Extracts (Moss Phytochemistry). Molecules. 2015;20(9):17221-43. https://doi. org/10.3390/molecules200917221 